Atmos. Chem. Phys., 19, 10787-10800, 2019

https://doi.org/10.5194/acp-19-10787-2019

(C) Author(s) 2019. This work is distributed under

the Creative Commons Attribution 4.0 License.

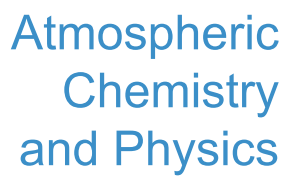

(c) (P)

\title{
Simulated coordinated impacts of the previous autumn North Atlantic Oscillation (NAO) and winter EI Niño on winter aerosol concentrations over eastern China
}

\author{
Juan Feng ${ }^{1}$, Jianping $\mathrm{Li}^{2,1}$, Hong Liao ${ }^{3}$, and Jianlei $\mathrm{Zhu}^{4}$ \\ ${ }^{1}$ College of Global Change and Earth System Science, Beijing Normal University, Beijing, China \\ ${ }^{2}$ Key Laboratory of Physical Oceanography-Institute for Advanced Ocean Studies, Ocean University of China and Qingdao \\ National Laboratory for Marine Science and Technology, Qingdao 266003, China \\ ${ }^{3}$ School of Environmental Science and Engineering, Nanjing University of Information Science \& Technology, \\ Nanjing, China \\ ${ }^{4}$ China-ASEAN Environmental Cooperation Center, Beijing, China
}

Correspondence: Juan Feng (fengjuan@bnu.edu.cn)

Received: 24 January 2019 - Discussion started: 4 March 2019

Revised: 21 May 2019 - Accepted: 10 June 2019 - Published: 27 August 2019

\begin{abstract}
The high aerosol concentration (AC) over eastern China has attracted attention from both science and society. Based on the simulations of a chemical transport model using a fixed emissions level, the possible impact of the previous autumn North Atlantic Oscillation (NAO) combined with the simultaneous El Niño-Southern Oscillation (ENSO) on the boreal winter $\mathrm{AC}$ over eastern China is investigated. We find that the NAO only manifests its negative impacts on the $\mathrm{AC}$ during its negative phase over central China, and a significant positive influence on the distribution of $\mathrm{AC}$ is observed over south China only during the warm events of ENSO. The impact of the previous NAO on the AC occurs via an anomalous sea surface temperature tripole pattern by which a teleconnection wave train is induced that results in anomalous convergence over central China. In contrast, the occurrence of ENSO events may induce an anomalous shift in the western Pacific subtropical high and result in anomalous southwesterlies over south China. The anomalous circulations associated with a negative $\mathrm{NAO}$ and $\mathrm{El} \mathrm{Niño} \mathrm{are} \mathrm{not} \mathrm{favorable} \mathrm{for} \mathrm{the}$ transport of $\mathrm{AC}$ and correspond to worsening air conditions over central and south China. The results highlight the fact that the combined effects of tropical and extratropical systems play a considerable role in affecting the boreal winter $\mathrm{AC}$ over eastern China.
\end{abstract}

\section{Introduction}

Atmospheric particles (i.e., aerosols) are the key pollutants that exhibit an important adverse impact on human health, environmental pollution, global climate change, and atmospheric visibility (IPCC, 2013). Aerosol particles may alter the precipitation rates and optical properties of clouds (Hansen et al., 1997), impacting the radiation balance of the entire Earth-atmosphere system via absorbing and scattering solar radiation (Jiang et al., 2017; Yue and Unger, 2017). A better understanding of aerosol variations is therefore important and useful for scientific and social endeavors.

Meteorology parameters, i.e., atmospheric temperature (Aw and Kleeman, 2003; Liao et al., 2015), boundary layer (Kleeman, 2008; Yang et al., 2016), wind (Zhu et al., 2012; Yang et al., 2014, 2017; Feng et al., 2017), and humidity (Ding and Liu, 2014), show a non-negligible impact on regional aerosol concentrations (ACs) by affecting deposition and transportation processes. Moreover, the intraseasonal and interannual variations in climatic phenomena could affect the spatial and temporal accumulation as well as the distribution of AC due to the associated variations in circulation and rainfall anomalies. For example, the monsoon onset could affect the seasonal variations in regional $\mathrm{AC}$ (Chen and Yang, 2008). The interannual variation of AC over East Asia is connected with the interannual variation of the East Asian winter monsoon (Jeong and Park, 2017; Lou et al., 
2016, 2018; Mao et al., 2017) and summer monsoon (EASM; Zhang et al., 2010; Zhu et al., 2012). The seasonal evolution of the El Niño-Southern Oscillation (ENSO) impacts the seasonal variations of AC over northern and south China (Feng et al., 2016a, 2017). The AC variation in the US is influenced by the Pacific Decadal Oscillation (Singh and Palazoglu, 2012). These findings suggest that the role of climate systems in impacting regional air quality cannot be ignored.

The North Atlantic Oscillation (NAO), reflecting largescale fluctuations in pressure between the subpolar low and subtropical high, is one of the most determinant and influential climate variability modes in the extratropical Atlantic Ocean (e.g., Hurrell, 1995; Gong et al., 2001; Visbeck et al., 2001). A negative (positive) polarity of the NAO is reflected by positive (negative) pressure anomalies over the high latitudes of the North Atlantic and negative (positive) pressure anomalies over the central North Atlantic. Both the positive and negative phases of NAO are accompanied by large-scale modulations in the location and intensity of the North Atlantic jet stream and storm track (Gong et al., 2001; Li and Wang, 2003). The surface-layer wind could vary in association with changes in the jet stream because of the NAO's quasi-barotropic characteristics, resulting in varied Ekman heat transport and basin-wide variations in the underlying sea surface temperature (SST; Marshall et al., 2001; Wu et al., 2009; $\mathrm{Wu}$ and $\mathrm{Wu}, 2018$ ).

The NAO massively impacts temperature and precipitation patterns over the US and central Europe; i.e., a wet and warm winter in Europe and mild and wet winter conditions would be expected accompanied by a positive NAO phase. Moreover, the NAO exhibits significant cross-seasonal impacts on the downstream regional climate. For example, it is reported that variation in boreal spring NAO influenced the subsequent intensity of the EASM from 1979 to 2006 (Wu et al., 2009). The linkage between the EASM and NAO has been further explored but on the interdecadal scale (Wu and Lin, 2012; Wu et al., 2012; Zuo et al., 2013), and it is suggested that the preceding spring NAO dominated the relationship of the NAO-EASM more than the simultaneous summer NAO; a similar result is seen in Zheng et al. (2016). $\mathrm{Xu}$ et al. (2013) presented the previous boreal summer NAO as significantly influencing the following September rainfall over central China. These studies highlight the important role of the NAO signal in the climate in East Asia, especially the cross-seasonal impacts, which are beneficial for seasonal forecasting.

In addition to the influence of the extratropics, the impact originating from the tropics is another important driver of climate anomalies in China. As the most dominant interannual variability of the tropical air-sea coupled system, the El Niño-Southern Oscillation (ENSO) exhibits profound influences on weather and climate around the world (e.g., Ropelewski and Halpert, 1987; Harrison and Larkin, 1998). The occurrence of ENSO phenomena displays significant effects in impacting global and regional oceanic and atmospheric anomalous patterns (e.g., Rasmusson and Carpenter, 1982; Trenberth, 1997). The seasonal climate variation in China is closely linked with the evolution of ENSO events. For example, increased rainfall is expected to be found over the Huaihe and Yangtze River valley, whereas less rainfall is seen over northern and south China during the decaying summer of an El Niño event (Zhang et al., 1996, 1999; Ye and Wu, 2018). During the developing autumn of an El Niño event, enhanced rainfall would be expected over south China due to the associated anomalous shift in the western Pacific subtropical high (WPSH). However, this is without a significant influence during the developing summer (Feng et al., 2016b). During the mature winter, both the warm and cold events show significant impacts on the temperature and rainfall anomalies over eastern China (Weng et al., 2009; Wu et al., 2011; Wu and Zhang, 2015; Li et al., 2019; P. Zhang et al., 2019a, b).

As shown above, both the NAO and ENSO significantly impact the climate over China. China is now suffering from relatively high aerosol loading, and this is commonly ascribed to increased emissions connected with speedy economic growth. However, as discussed above, the role of meteorological conditions in affecting the AC cannot be ignored. Accordingly, it is of interest to explore the possible impacts of the NAO and ENSO on the distributions of AC over China. The possible impacts of the NAO on aerosol have been discussed by Moulin et al. (1997) and Jerez et al. (2013); however, they concentrated on its influences on the North Atlantic Ocean and Europe, respectively. Feng et al. (2016a) indicated the potential effects of El Niño on the $\mathrm{AC}$ over China but with a focus on the seasonal evolution. Does the NAO therefore exhibit significant impacts on the AC? And how does the combination of the NAO and ENSO affect the distribution of AC over China? These questions are important as both of them show an important modulation of the climate over China.

The above discussion provides the main motivation of the present work. The conditions in boreal winter are discussed in the present work, as this time corresponds to the heat supply season and the AC peak over China during this season. The coordinated role of the previous autumn (September to November, SON) NAO and the simultaneous ENSO is compared to that of the NAO alone, as well as the involved physical mechanisms. The rest of this paper is arranged as follows. The model, datasets, and methodology employed are presented in Sect. 2. The possible impacts of the NAO and ENSO on the AC are explored in Sect. 3. Section 4 discusses the involved physical mechanisms. Section 5 provides the discussion and conclusions. 


\section{Datasets, simulations, and methodology}

\subsection{Datasets}

The input background meteorological variables of the GEOS-Chem model show a high degree of uniformity with current widely used reanalyses (e.g., Zhu et al., 2012; Yang et al., 2014). Here, the following are used to verify the reliability of the Goddard Earth Observing System version 4 (GEOS-4): the sea level pressure (SLP) in the National Centers for Environmental Prediction/National Center for Atmospheric Research (NCEP/NCAR) reanalysis (Kalnay et al., 1996) with a $2.5^{\circ}$ latitude $\times 2.5^{\circ}$ longitude resolution; and the UK Meteorological Office Hadley Centre's sea ice and SST datasets (HadISST; Rayner et al., 2003) with a $1^{\circ}$ latitude $\times 1^{\circ}$ longitude resolution.

\subsection{GEOS-Chem simulations}

The influences of the NAO on the simulated AC over China are examined using a three-dimensional tropospheric chemistry model, i.e., GEOS-Chem (version 8.02.01; Bey et al., 2001). The model is driven by assimilated meteorological fields from the GEOS-4 of the NASA Global Modeling and Assimilation Office, with a $2^{\circ}$ latitude $\times 2.5^{\circ}$ longitude resolution and 30 hybrid vertical levels. This model contains a detailed coupled treatment of tropospheric ozone- $\mathrm{NO}_{x}-$ hydrocarbon chemistry, as well as aerosols and their precursors, containing nitrate, black carbon, sulfate, sea salt, ammonium, mineral dust, dust aerosols, and organic carbon (Bey et al., 2001; Liao et al., 2007). The aerosol dry and wet depositions follow Wesely (1989) and Liu et al. (2001), with details in Wang et al. (1998). According to Liao et al. (2007), the ACs were defined by $\mathrm{PM}_{2.5}$ as follows:

$$
\begin{aligned}
{\left[\mathrm{PM}_{2.5}\right] } & =1.37 \times\left[\mathrm{SO}_{4}^{2-}\right]+1.29 \times\left[\mathrm{NO}_{3}^{-}\right] \\
& +[\mathrm{POA}]+[\mathrm{BC}]+[\mathrm{SOA}] .
\end{aligned}
$$

$\mathrm{SO}_{4}^{2-}, \mathrm{NO}_{3}^{-}, \mathrm{POA}, \mathrm{BC}$, and $\mathrm{SOA}$ are the aerosols particles of sulfate, nitrate, primary organic aerosol, black carbon, and second organic aerosol, respectively. Sea salt aerosols and mineral dust are not considered because measurements indicate that they are not the major aerosol species in eastern China during winter (Xuan et al., 2000; Duan et al., 2006).

The anthropogenic emissions in GEOS-Chem and the experiment design are similar to Zhu et al. (2012), in which the biomass burning emissions and anthropogenic emissions are fixed at the 2005 level in the simulation. That is, the observed variations in the distributions of $\mathrm{AC}$ as seen below were due to the variations in meteorological conditions associated with climate events. Due to the longevity of the GEOS-4 datasets, the period 1986-2006 is focused on. GEOS-Chem is a wellrecognized atmospheric chemistry model and is widely utilized due to its capability to characterize the seasonal, interannual, and decadal variations of pollutant aerosols in East
Asia and beyond (e.g., Zhu et al., 2012; Yang et al., 2014, 2016; Feng et al., 2017). The good performance and wide application of GEOS-Chem provide confidence for employing the model to investigate the coordinated impacts of NAO and El Niño on the AC over eastern China.

\subsection{NAO index and Niño3 index}

The NAO index (NAOI) is employed to quantify the variations in the NAO phase (Hurrell et al., 1995; Gong and Wang, 2001). The definition of the NAOI follows Li and Wang (2003) and is calculated as the zonal mean SLP difference between $35^{\circ} \mathrm{N}$ (i.e., refers to the midlatitude center) and $65^{\circ} \mathrm{N}$ (i.e., refers to the high-latitude center) from $80^{\circ} \mathrm{W}$ to $30^{\circ} \mathrm{E}$ over the North Atlantic according to

$\mathrm{NAOI}=\hat{P}_{35^{\circ} \mathrm{N}}-\hat{P}_{65^{\circ} \mathrm{N}}$

where $P$ is the monthly mean SLP averaged from $80^{\circ} \mathrm{W}$ to $30^{\circ} \mathrm{E}, \hat{P}$ is the normalized value of $P$, and the subscripts indicate latitudes. For a given month $m$ in year $n$, the normalization $\hat{P}$ is defined as follows:

$\hat{P}_{n, m}=\frac{P_{n, m}^{\prime}}{S_{P}}$,

where $P_{n, m}^{\prime}$ is the monthly pressure anomaly of $P_{n, m}$, with a departure from the period 1986-2006, and $S_{P}$ is the total standard deviation of the monthly anomaly $P^{\prime}{ }_{n, m}$.

$S_{P}=\sqrt{\frac{1}{12 \times 21} \sum_{i=1986}^{2006} \sum_{j=1}^{12} P_{j, i}^{\prime 2}}$

The monthly NAOI is calculated based on the monthly mean SLP from both the NCEP/NCAR and GEOS-4 assimilated meteorological dataset for 1986-2006. The boreal autumn NAOI is defined as the average of the monthly NAOI during September, October, and November (Fig. 1). The series of NAOI show strong interannual variations, and the two series based on GEOS-4 and NCEP/NCAR are closely correlated with each other with a significant coefficient of 0.98 , implying that the GEOS-4 dataset could capture the variation in the NAO.

El Niño events were defined as a standardized 3-month running-mean Niño3 index (areal mean SST averaged over $150-90^{\circ} \mathrm{W}, 5^{\circ} \mathrm{N}-5^{\circ} \mathrm{S}$ ) above $0.5^{\circ} \mathrm{C}$ and persisting for at least 6 months. The skin temperature (i.e., SST over ocean and surface air temperature on land) was employed to obtain the Niño3 index because SST is not available in the GEOS4 meteorological dataset. The boreal winter Niño3 index is calculated as the average of the monthly Niño3 during December, January, and February; i.e., winter 1997 is for the December 1997 and January and February 1998. The boreal winter Niño3 indices based on GEOS-4 and HadISST are significantly correlated with each other (Fig. 1), with a coefficient of 0.99 . The high correlations among the indices further indicate the reliability of the model data. 

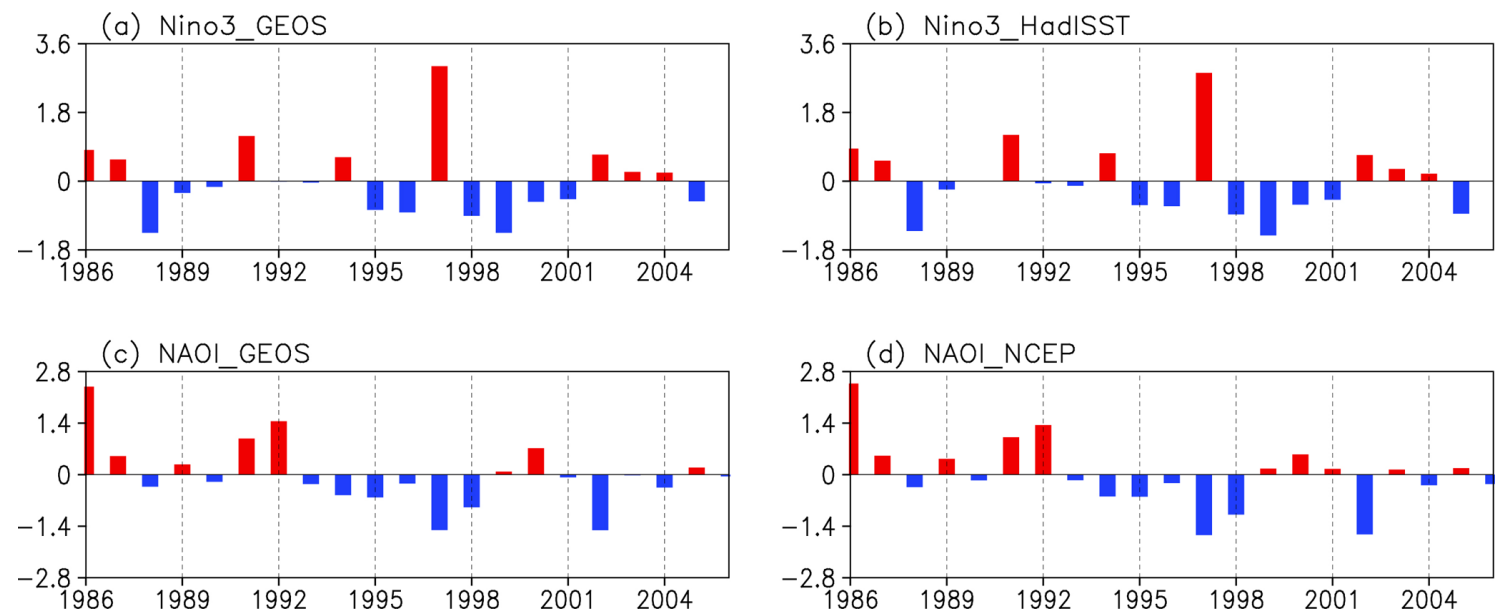

Figure 1. (a) Time series of the Niño3 index based on the GEOS-4 input skin temperature data for $1986-2006\left({ }^{\circ} \mathrm{C}\right)$. Panel (b) is similar to (a) but based on HadISST. (c) Time series of the NAO index based on the GEOS-4 input sea level pressure. Panel (d) is similar to (c) but based on the NCEP/NCAR reanalysis.

\section{Influences of the NAO and EI Niño on the AC over China}

\subsection{Climatological characteristics of the AC}

The spatial distribution of the standard deviation of boreal winter AC is shown in Fig. 2. Eastern China $\left(105^{\circ} \mathrm{E}\right.$ eastward, $35^{\circ} \mathrm{N}$ southward) shows high loading of aerosols in both the column and surface-layer concentrations (figure not shown). Further, the variance of winter AC over eastern China is most pronounced compared to other regions during this season (Fig. 2a, b). As an evident monsoonal region, eastern Asia is influenced by the winter monsoon; i.e., a strong Aleutian low is seen in the North Pacific, and the Asian continent is controlled by the Siberian high during boreal winter. The strong pressure gradient between the Siberian high and Aleutian low results in strong northwesterlies prevailing over eastern China (Fig. 2c).

\subsection{Relationships between the AC-NAO and El Niño}

The spatial distributions between the surface AC, previous autumn NAOI, and simultaneous winter Niño3 index are presented in Fig. 3. Positive correlations are seen over south $\left(30^{\circ} \mathrm{N}\right.$ south) and northwest China in the correlations with the Niño3 index, indicating that a warm ENSO event would be associated with high AC over south and northwest China. In contrast, negative correlations over south and central China are observed in the correlations with autumn NAO, implying that a positive NAO phase is linked with a lower AC over these regions, thus favoring better air conditions. The analysis suggests that the ENSO and NAO show opposite effects on AC over south China; i.e., the NAO displays a negative impact and the ENSO displays a positive impact. However, the relationship between the autumn NAOI and winter
Niño3 index is insignificant with a correlation of -0.08 during the period 1986-2006.

The above relationships are further examined in their positive and negative phases, as strong asymmetry was reported in the climatic impacts of the NAO (Xu et al., 2013; Zhang et al., 2015) and ENSO (Cai and Cowan, 2009; Karori et al., 2013; Feng et al., 2016b). The asymmetric influences of the NAO and ENSO on AC are obvious in the spatial distributions of the linear correlation coefficients (Fig. 4). During El Niño events, south China is impacted by significant positive correlations; in contrast, a nonsignificant correlation is observed over this region during La Niña events. This point implies that significant relationships between the ENSO and AC over south China are mainly connected with warm events, i.e., El Niño. The negative correlations between the NAO and AC mainly occurred in the negative phase of the NAO, and the significant correlations are mainly located in central China (from 28 to $40^{\circ} \mathrm{N}$ ). Thus, the ENSO affects the distribution of $\mathrm{AC}$ in south China, but the impact is manifested during warm events. Similarly, the effect of the NAO on the distribution of $\mathrm{AC}$ over central China is only apparent during its negative phase.

The results suggest that if the occurrence of a negative polarity of NAO overlaps an El Niño event, the combined effects of the two may further worsen the AC over eastern China. In contrast, a single occurrence of a negative NAO event is associated with above-normal AC over central China. The statistically significant impacts of negative NAO and El Niño events on the AC could be further established by a case study. Two cases, i.e., the co-occurrence of an El Niño event and a negative $\mathrm{NAO}$ as well as a single negative NAO event, were chosen to further explore the effect of the NAO and El Niño on the AC over China. From 1986 to 2006, there are two years (1997 and 2002) with equivalent negative values of autumn NAOI (-1.507 in 1997, and -1.510 in 2002). 

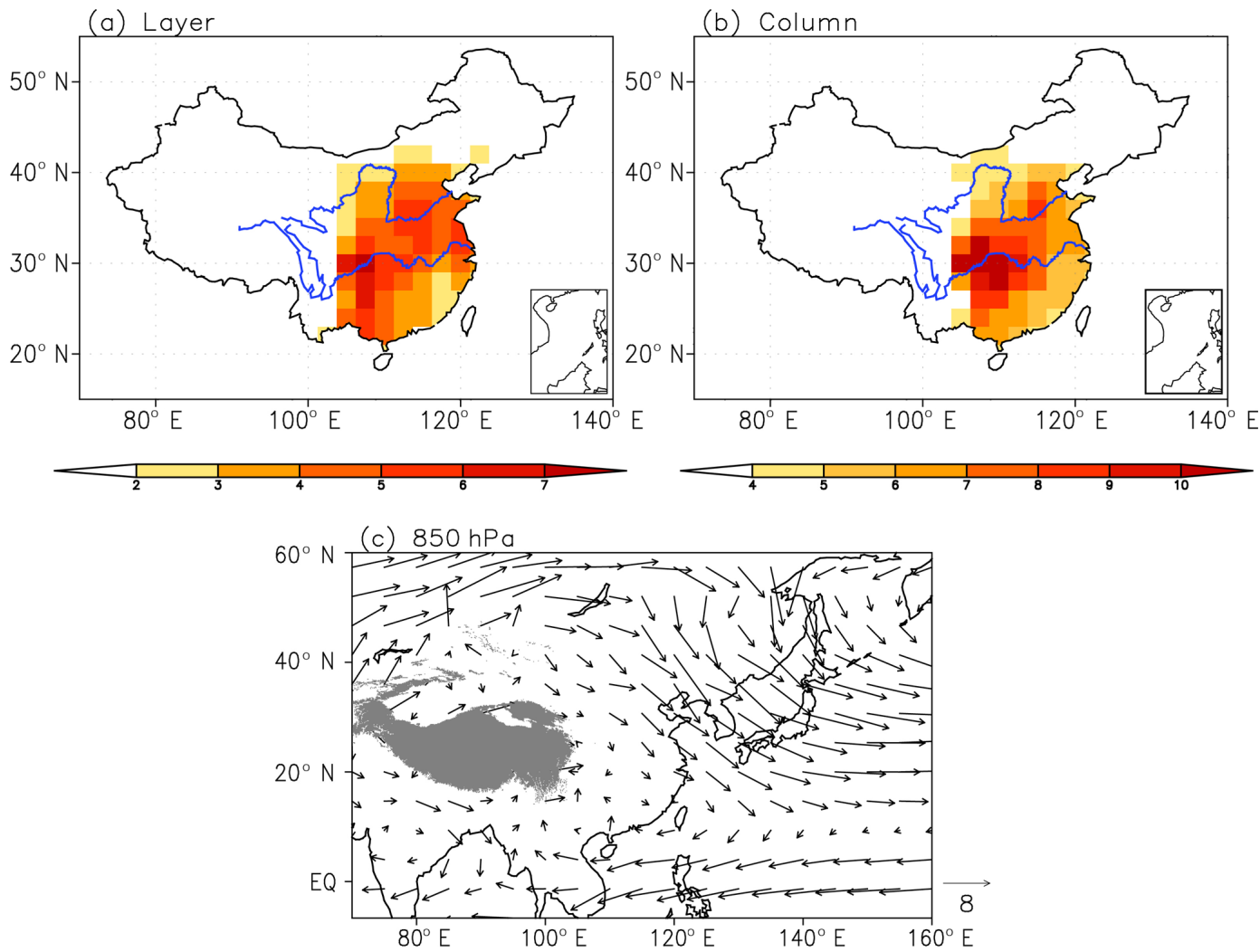

Figure 2. The standard deviation of the simulated (a) surface-layer $\mathrm{PM}_{2.5}$ concentrations $\left(\mu \mathrm{g} \mathrm{m}^{-3}\right)$ and (b) column burdens of $\mathrm{PM}_{2.5}$ $\left(\mathrm{mg} \mathrm{m}^{-2}\right)$ during boreal winter averaged from 1986 to 2006. (c) The horizontal distribution of boreal winter climatological mean wind at $850 \mathrm{hPa}\left(\mathrm{m} \mathrm{s}^{-1}\right)$; shading indicates the Tibetan Plateau.
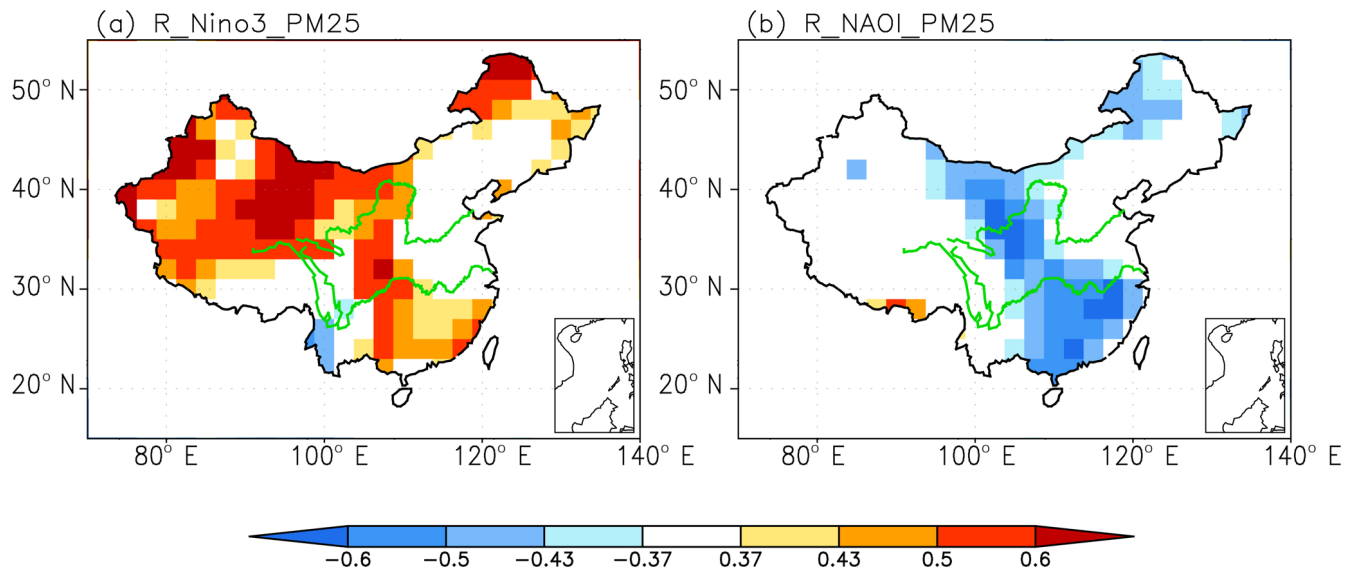

Figure 3. (a) The spatial distribution of the correlation coefficients between surface-layer $\mathrm{PM}_{2.5}$ concentrations and the Niño3 index. (b) As in (a) but for correlations with the NAOI. Color shading indicates a significant correlation at the 0.1 level $(0.37$ is the critical value for significance at the 0.1 level).

Winter 1997 corresponds to the strongest El Niño in the past 120 years, and winter 2002 corresponds to a neutral ENSO event. Consequently, the anomalous distribution of AC during these two years is discussed in the context of comparing the combined and individual effects of a negative NAO and El Niño in impacting the distribution of AC over eastern China. 

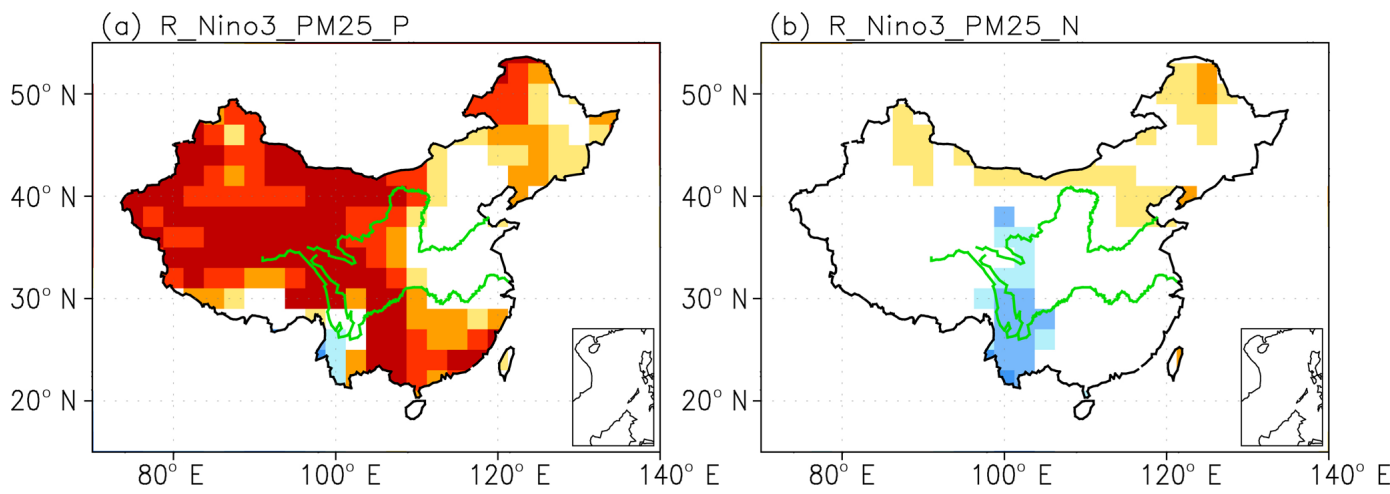

(c) R_NAOI_PM25_P

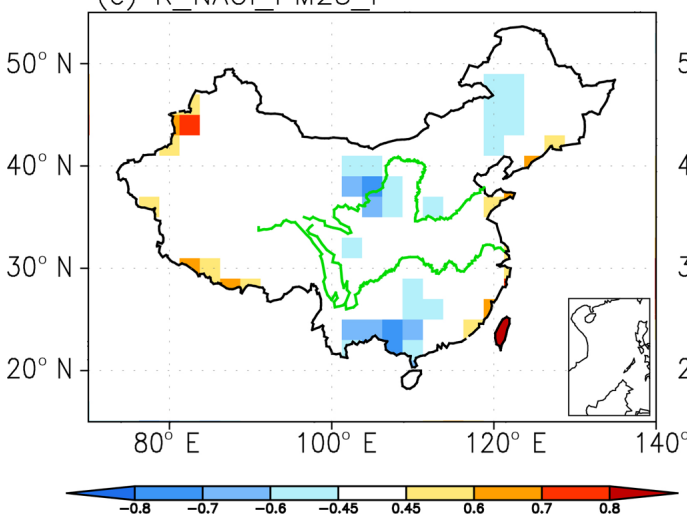

(d) R_NAOI_PM25_N

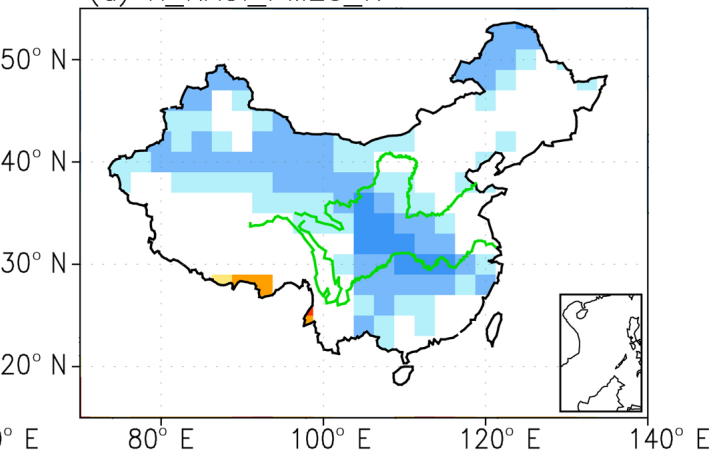

Figure 4. Spatial distribution of the correlation coefficients between (a) positive and (b) negative Niño3 index values and surface-layer PM 2.5 concentrations. Panels $(\mathbf{c}, \mathbf{d})$ are as $(\mathbf{a}, \mathbf{b})$ but for the NAOI. Color shading indicates a significant correlation $(0.35$ and 0.45 are the critical values for significance at the 0.2 and 0.1 level, respectively).
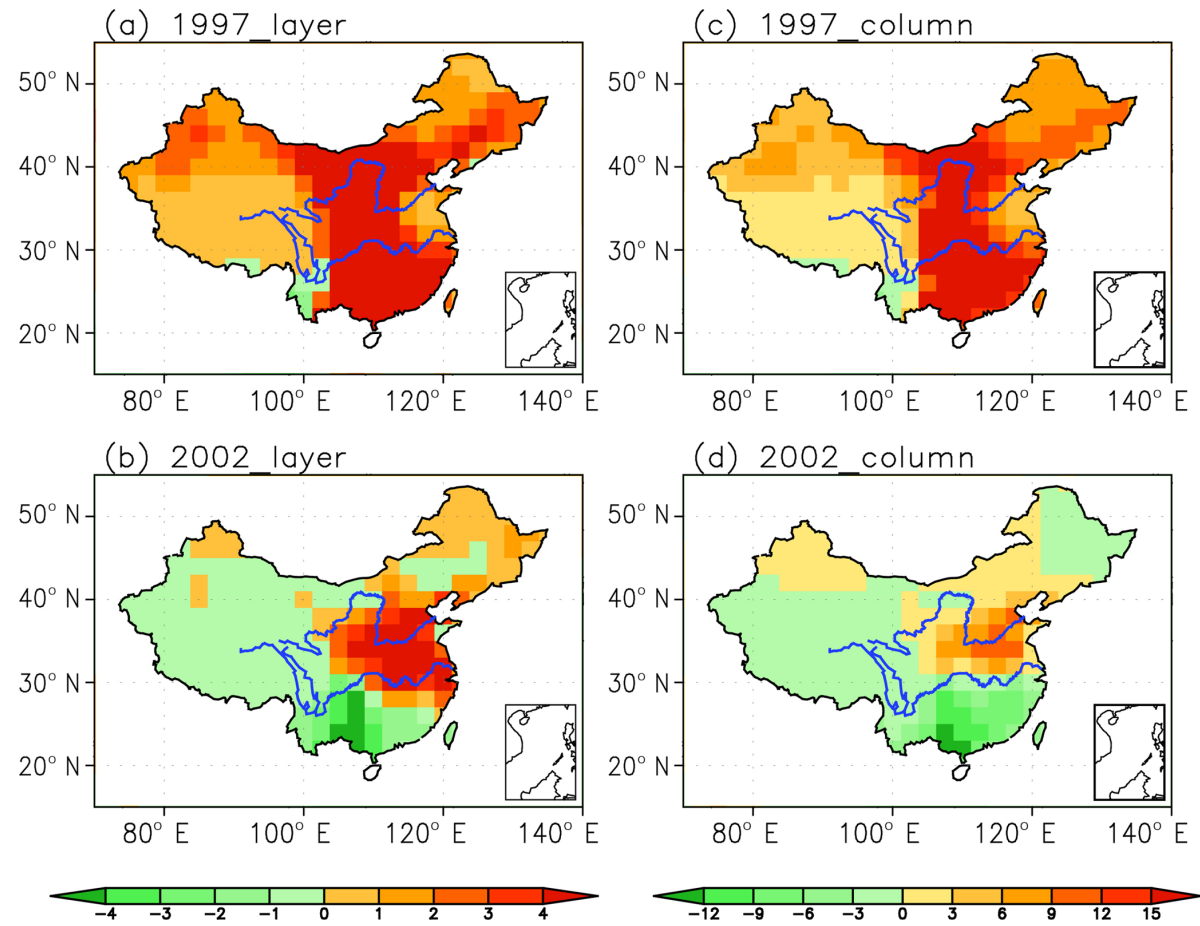

Figure 5. The spatial distribution of simulated anomalous (a, b) surface-layer $\mathrm{PM}_{2.5}$ concentrations $\left(\mu \mathrm{g} \mathrm{m}{ }^{-3}\right)$ and $(\mathbf{c}, \mathbf{d})$ column burdens of $\mathrm{PM}_{2.5}\left(\mathrm{mg} \mathrm{m}^{-2}\right)$ during the boreal winters of $1997(\mathbf{a}, \mathbf{c})$ and $2002(\mathbf{b}, \mathbf{d})$. 

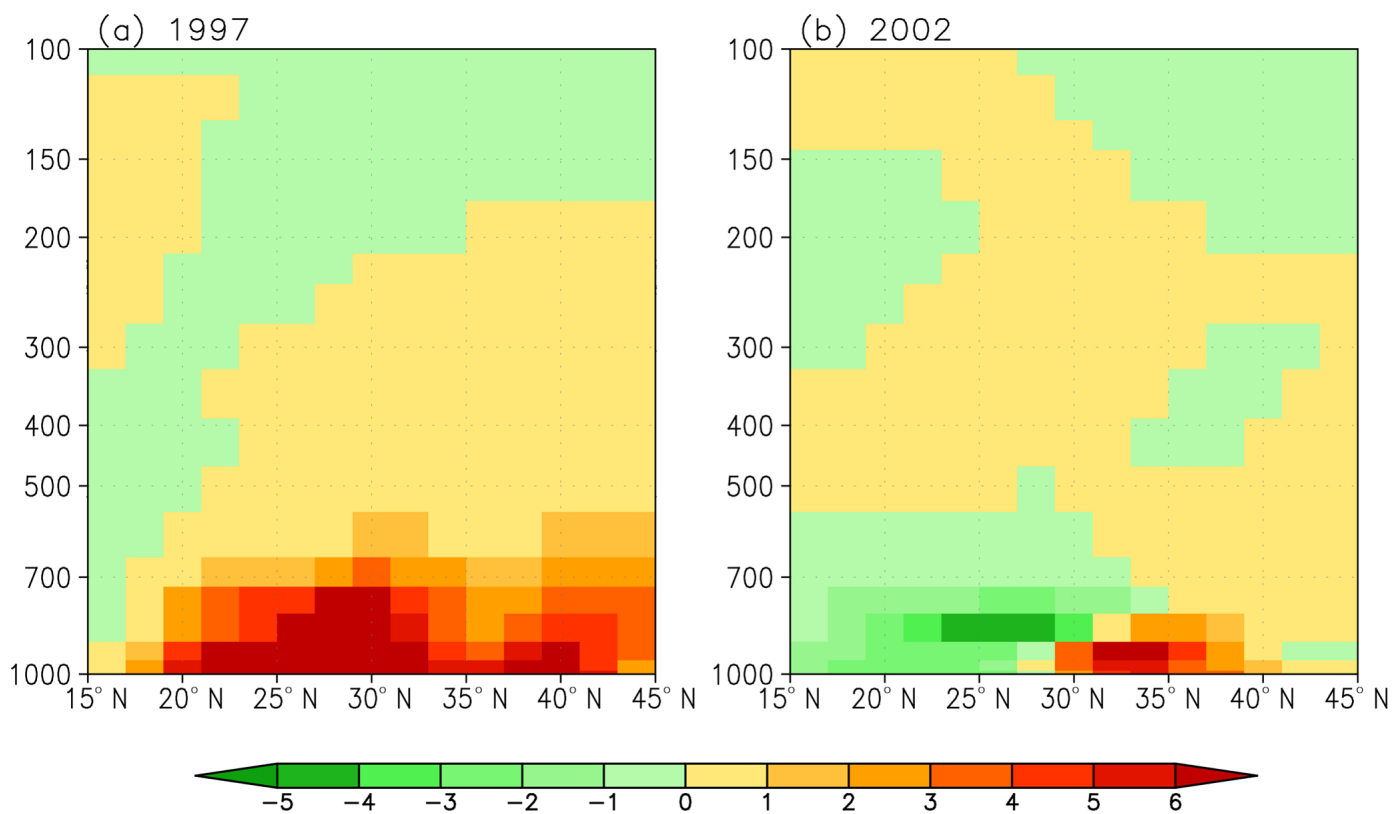

Figure 6. The pressure-latitude distribution of zonally averaged $\mathrm{PM}_{2.5}$ anomalies over $105-120^{\circ} \mathrm{E}$ during the winters of (a) 1997 and (b) $2002\left(\mu \mathrm{g} \mathrm{m}^{-3}\right)$.

\subsection{Influences of the NAO and EI Niño vs. the NAO on the $\mathrm{AC}$}

Figure 5 presents the layer and column AC anomalies simulated for the winters of 1997 and 2002 with a departure from the climatological mean. Under the combined influence of a negative NAO and El Niño (1997), positive aerosol concentration anomalies are observed over eastern China (Fig. 5a, c). In addition, simulated enhanced AC was observed over central China in winter 2002 under the impacts of a negative NAO (Fig. 5b, d). These characteristics are also apparent in the vertical distribution (Fig. 6), which shows the zonal mean anomalies averaged over eastern China (105$120^{\circ} \mathrm{E}$ ). For winter 1997, an increased AC covers the whole of eastern China, with maximum values at approximately $30^{\circ} \mathrm{N}$, where the effects of the NAO and El Niño overlap (Fig. 4a, d). The combined effects of the anomalies show a consistent distribution in the vertical levels (Fig. 6). In contrast, clearly increased $\mathrm{AC}$ anomalies are seen in central China, with the maximum at approximately $32^{\circ} \mathrm{N}$ during winter 2002.

The consistent results between the correlations and anomalies for the two cases highlight the role of negative $\mathrm{NAO}$ and El Niño events in determining the distribution of AC over eastern China. The NAO shows a significant influence on the central China AC that is only apparent during its negative phase, and the ENSO impacts the AC over south China mainly during warm events.

\section{Mechanisms of the effects of the NAO and EI Niño on the $\mathrm{AC}$}

\subsection{Role of circulation transport}

The corresponding reverse role of the NAO and El Niño in impacting the distribution of $\mathrm{AC}$ is mainly derived from their contrasting effects on circulation. Figure 7 shows the SLP and surface wind anomalies during the autumns of 1997 and 2002, presenting an anomalously weak autumn NAO pattern. The negative phase of the NAO displays as an anomalous SLP dipole structure between the middle-latitude North Atlantic Ocean and Arctic, i.e., with positive SLP anomalies at the Arctic over the Atlantic sector and anomalous negative SLP at middle latitudes. Although the locations of the anomalous pressure centers in the two negative NAO events show differences, the anomalous SLP amplitude in the two events is similar, i.e., with greater negative SLP anomalies at midlatitudes, indicating that the pressure gradient of the two NAO negative events is similar. The oscillation in the SLP is connected with anomalies in the surface wind across the North Atlantic, i.e., associated with an anomalous cyclonic circulation centered at approximately $45^{\circ} \mathrm{N}$ and anticyclonic circulation anomalies around Iceland. During boreal winter and spring, an anomalous NAO could result in a tripole SST anomalous pattern in the North Atlantic Ocean (Watanabe et al., 1999). A similar SST tripole pattern is observed during boreal autumn, with warm SST anomalies at high and low latitudes and negative SST anomalies at middle latitudes in the North Atlantic sector (Fig. 8a, c). Note that the negative SST anomalies during 1997 display an east-west di- 

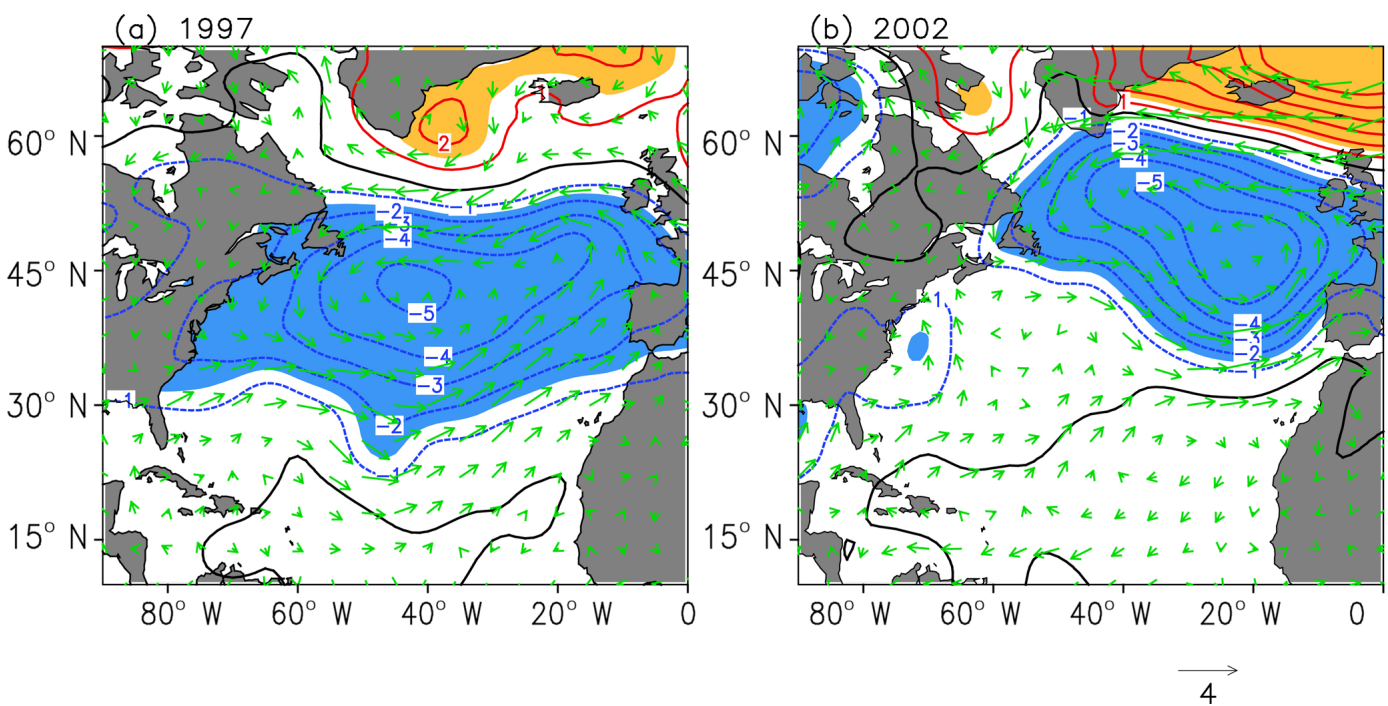

Figure 7. The horizontal distribution of surface wind $\left(\mathrm{m} \mathrm{s}^{-1}\right)$ and surface-level pressure (hPa) based on assimilated meteorological data during the autumns of (a) 1997 and (b) 2002.
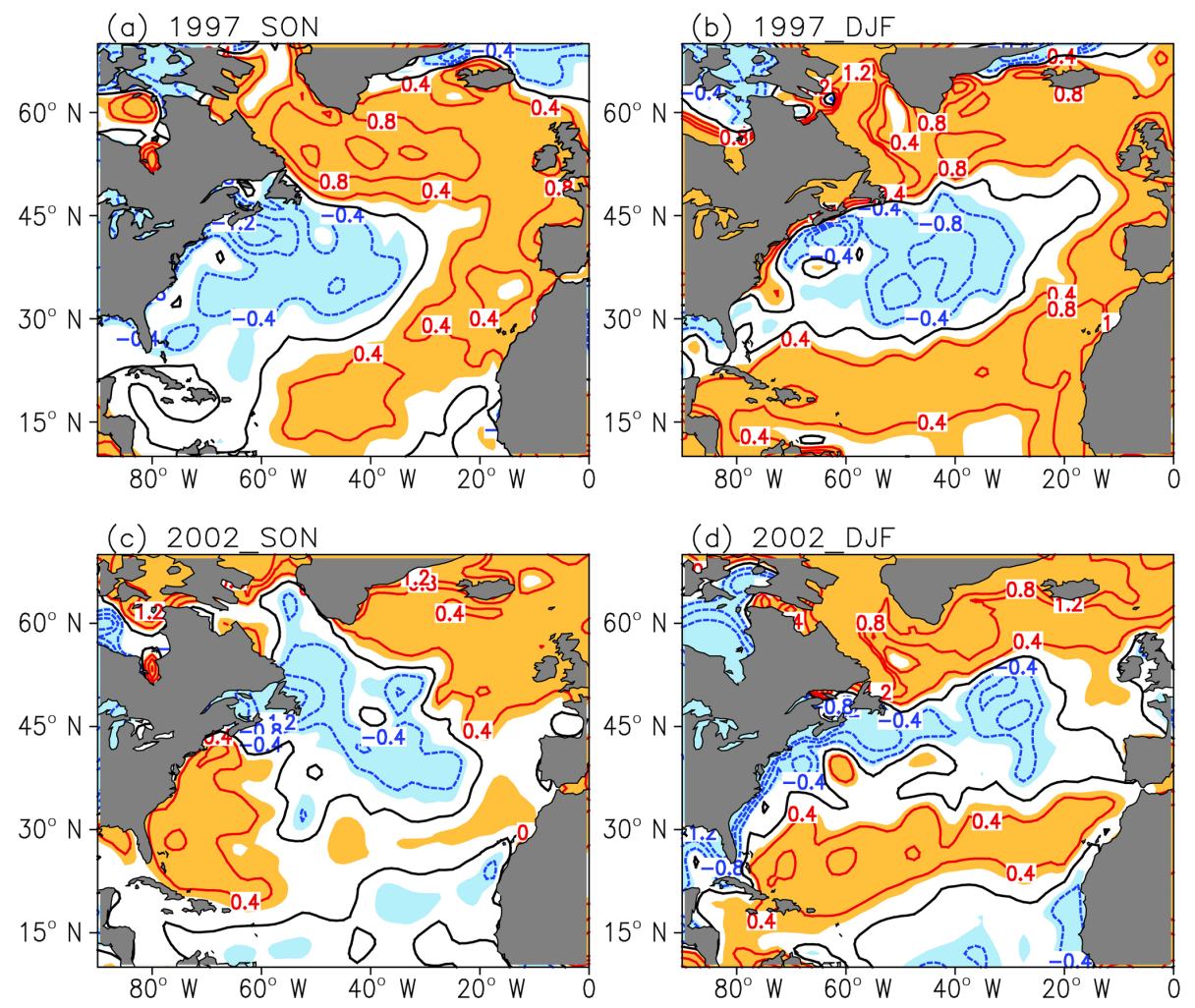

Figure 8. The horizontal distribution of skin temperature anomalies $\left({ }^{\circ} \mathrm{C}\right)$ based on assimilated meteorological data during the (a) autumn and (b) winter of 1997. Panels (c, d) are as (a, b) but during 2002. 

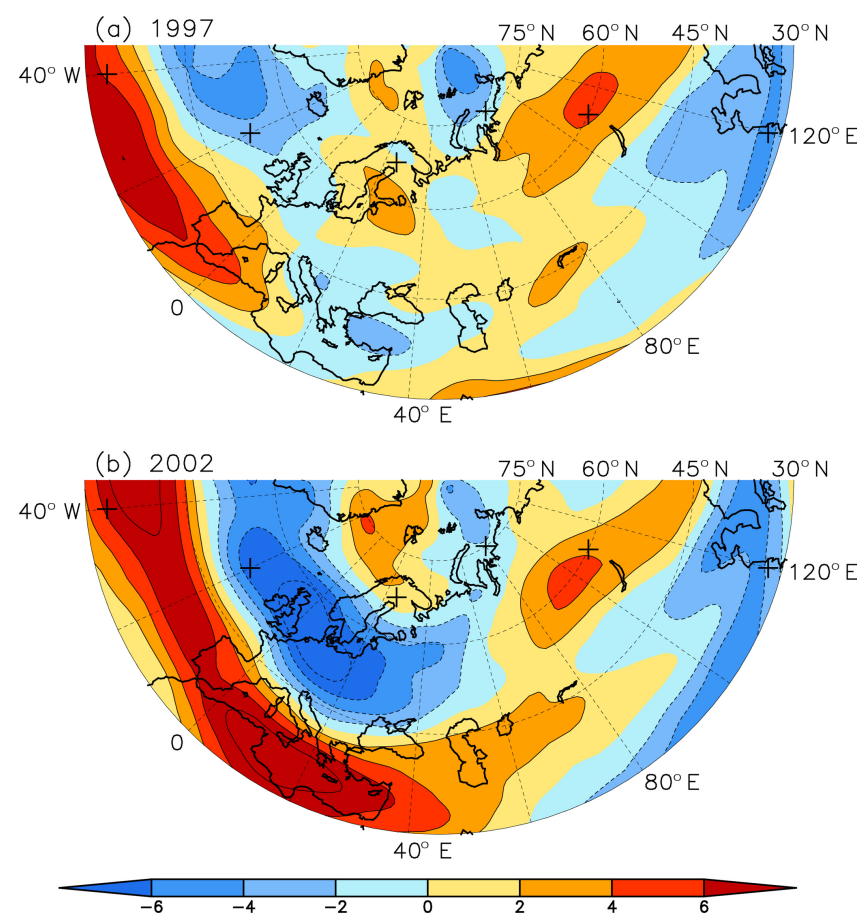

Figure 9. Horizontal distribution of the divergence $\left(10^{-5} \mathrm{~s}^{-1}\right)$ at $300 \mathrm{hPa}$ during the winters of (a) 1997 and (b) 2002. The crosses denote the centers of action of the AEA pattern.

rection but originated from a northwest-southeast direction during 2002 due to the different locations of anomalous SLP (Fig. 7).

The North Atlantic anomalous SST tripole pattern is due to the feedback between wind and SST. The anomalous anticyclonic (cyclonic) circulation weakens (strengthens) the prevailing westerlies, which would result in a decreased (increased) loss of heat and warmer (cooler) anomalies in Ekman heat transport (Xie, 2004; Wu et al., 2009); this is connected to warmer (cooler) local SST. Due to the short memory of the atmosphere, the cross-seasonal influences of the NAO on the AC should be preserved in the boundary layer forcing such as SST (Charney and Shukla, 1981). This anomalous tripole SST pattern could persist to the following winter (Fig. 8b, d), as the anomalous tripole SST patterns during winter and autumn show high consistencies in both 1997 and 2002, with significant spatial correlation coefficients of 0.32 and 0.51 between the autumn and winter tripole SST patterns for 1997 and 2002, respectively.

Figure 9 shows anomalous divergence at the upper troposphere. The occurrence of a negative NAO phase is accompanied by an anomalous teleconnection wave train over northern Eurasia (AEA) in the upper troposphere during boreal summer (Li and Ruan, 2018). This anomalous teleconnection pattern is also observed during boreal winter, with a shift in the precise locations. Under the influence of the anomalous downstream teleconnection, north China is influenced by convergence anomalies, with the center positioned over central China (Fig. 9). The anomalous convergence is clearly seen in both the upper and lower troposphere, accompanied by anomalous easterlies or southeasterlies over central China (Fig. 10). The direction of the anomalous wind is opposite to the climatological winds, which would weaken the climatological wind and is unfavorable for the transport of aerosol concentration, leading to increased AC over central China, as displayed in Fig. 5.

For the winter 1997, corresponding to the El Niño mature phase, south China was influenced by an evident anomalous divergence at the lower troposphere, indicating anomalous anticyclonic circulation over the coastal regions (Fig. 10a). Anomalous southwesterlies prevailed in south China, implying weakened northerlies. That is, the anomalous meteorological conditions are unfavorable for aerosol transport in the region and would result in worsened air quality. In contrast, for the winter 2002, south China was controlled by an anomalous divergence because the main body of the WPSH shifts to the south of south China (Fig. 10b). The anomalous circulation was favorable for the emission of pollutants. Moreover, an evident anomalous divergence was observed in south China in the winters of 1997 and 2002 at the upper troposphere; however, the corresponding distribution of AC over this region is different. This highlights the role of El Niño in impacting the circulation anomalies over south China, as mentioned above. The occurrence of El Niño events would be accompanied by a northwest shift of the WPSH during boreal winter and enhanced southwesterlies over south China (Weng et al., 2009). In addition, column ACs are mainly contributed by concentrations at that lower troposphere, suggesting that the lower troposphere circulation may play a vital role in impacting the $\mathrm{AC}$ over south China.

\subsection{Role of wet deposition}

In addition to the contribution of circulation anomalies to the distribution of $\mathrm{AC}$, changes in wet deposition also could affect the distribution of AC. Figure 11 presents the simulated wet deposition anomalies during the winters of 1997 and 2002. Negative anomalies occurred over eastern China during the winter of 1997, which are favorable for increased AC. This suggests that wet deposition plays a positive role in the enhanced AC during winter 1997. Positive anomalies were observed over central China in the 2002 winter, inconsistent with the AC anomalies. The anomalous wet deposition during winter 1997 is parallel to the AC anomalies over eastern China; however, it is not consistent with that for the winter of 2002. This suggests that the role of wet deposition in impacting the AC over eastern China creates uncertainties, showing a strong regional dependence. The impact of wet deposition on the AC was examined with a sensitivity experiment by turning off the wet deposition (Fig. 11c, d). An anomalous AC distribution similar to those shown in Fig. 5 


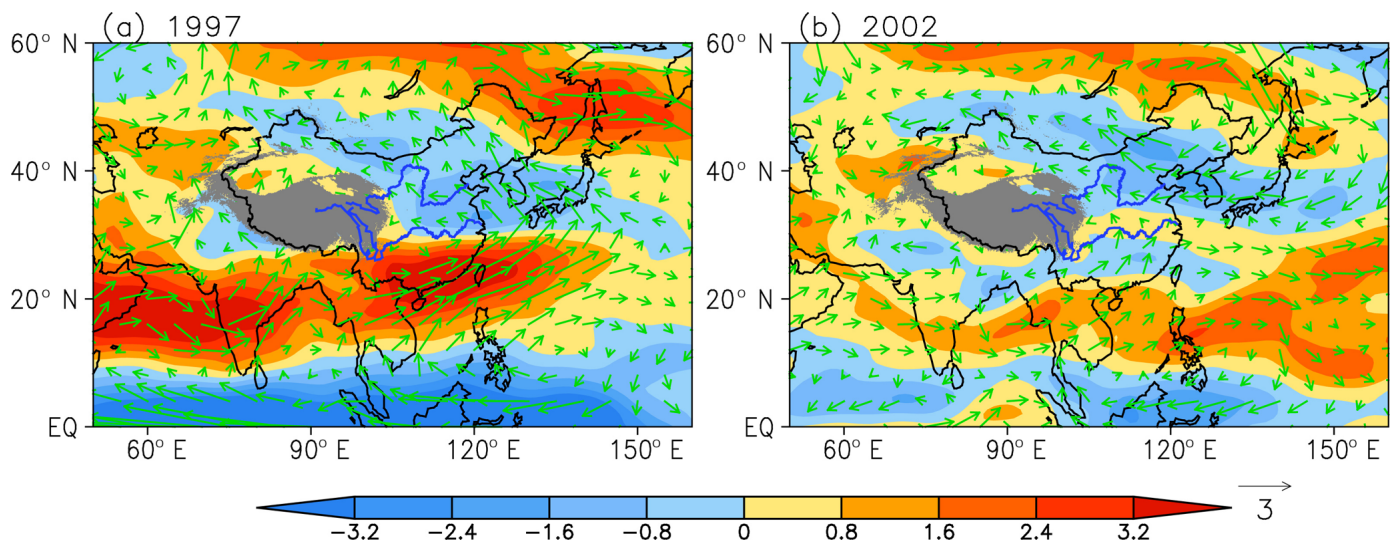

Figure 10. Horizontal distribution of $850 \mathrm{hPa}$ wind anomalies (vectors; $\mathrm{m} \mathrm{s}^{-1}$ ) and divergence (shading; $10^{-5} \mathrm{~s}^{-1}$ ) at $700 \mathrm{hPa}$ during the winters of (a) 1997 and (b) 2002.
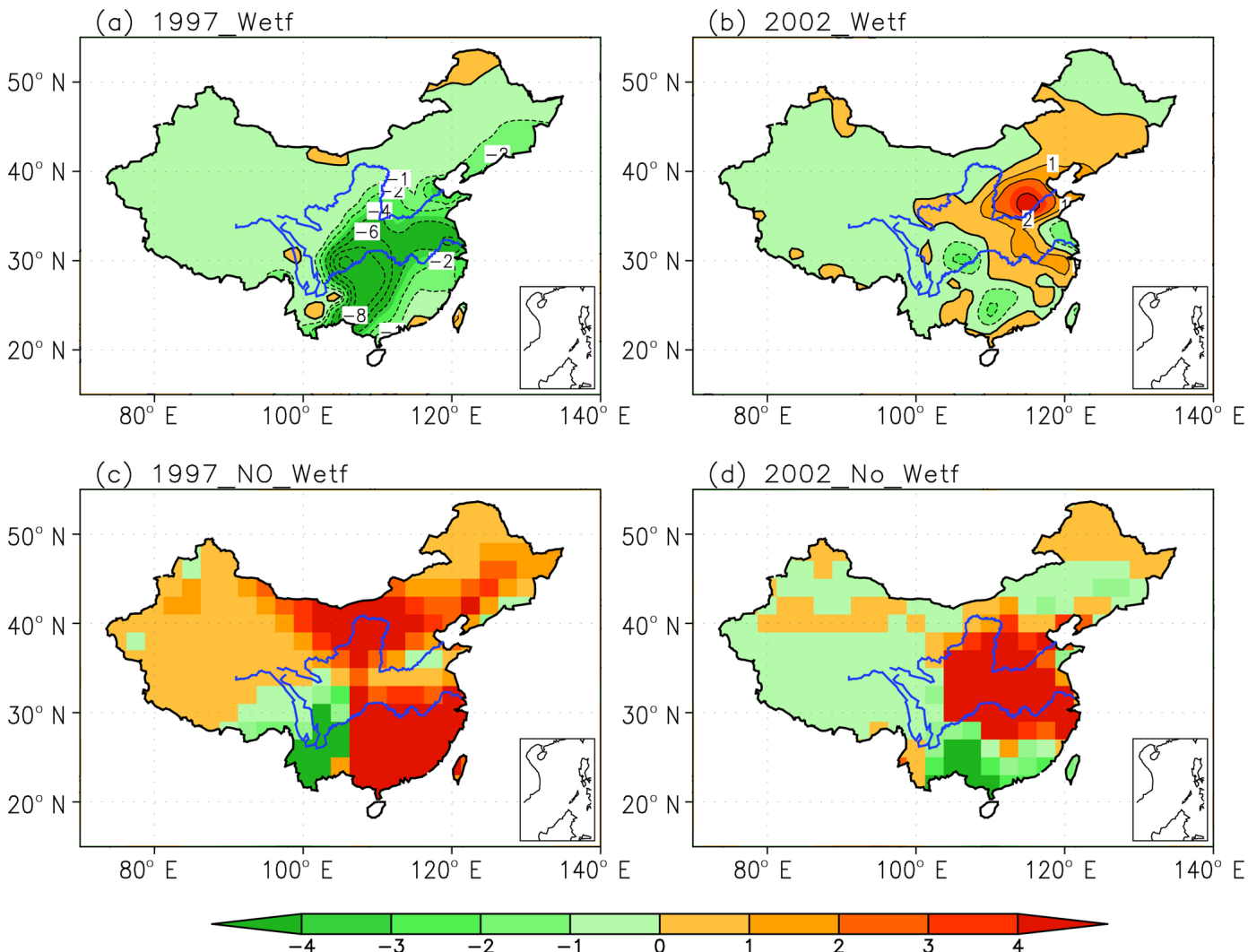

Figure 11. The spatial distribution of the vertically integrated wet deposition flux anomalies during the winters of (a) 1997 and (b) 2002 . Panels $(\mathbf{c}, \mathbf{d})$ are as $(\mathbf{a}, \mathbf{b})$ but for the anomalous distribution of aerosol concentrations when wet deposition is turned off. 
was observed, confirming that the role of wet deposition in impacting the distribution of $\mathrm{AC}$ is not as important as the circulation.

\section{Summary and discussion}

Using simulations of the GEOS-Chem model with fixed emissions, the coordinated impacts of the previous autumn $\mathrm{NAO}$ and simultaneous ENSO on the boreal winter AC over eastern China are investigated. The results demonstrate that both the NAO and ENSO show asymmetry impacts on the boreal winter $\mathrm{AC}$ over eastern China; i.e., the NAO manifests negative impacts over central China during its negative phase and the ENSO positively impacts the AC over south China significantly during its warm events. Consequently, the possible impacts of two cases were investigated to ascertain the role of the NAO and ENSO in the distribution of AC over China. In winter 1997, there was a co-occurrence of negative NAO and an El Niño event, and winter 2002 corresponds to a negative NAO phase and neutral ENSO. For the winter of 1997, obviously enhanced ACs were observed over eastern China, with a maximum at approximately $30^{\circ} \mathrm{N}$, where the impacts of the NAO and El Niño overlap. For the winter of 2002, there were generally increased ACs over central China. These results suggest that the co-occurrence of a negative NAO and El Niño could worsen air conditions over eastern China, and a single negative NAO is associated with increased AC over central China.

The cross-seasonal impacts of the preceding autumn NAO on the following winter AC over China can be explained by the coupled air-sea bridge theory ( $\mathrm{Li}$ and Ruan, 2018). The preceding negative NAO exerts significant influences on winds due to the adjustment of the wind to the anomalous SLP. The associated anomalous wind could affect the underlying regional SST, resulting in an anomalous SST tripole pattern over the North Atlantic. Since the North Atlantic SST exhibits strong persistence, this anomalous SST pattern could persist into the subsequent winter and induce an anomalous AEA teleconnection wave train in the upper troposphere, with anomalous convergence over central China. Thus, central China is controlled by anomalous southeasterlies or easterlies, which weaken the climatological northwesterlies and induce increased AC over central China. In contrast, the occurrence of El Niño is linked to warm SST anomalies over the tropical eastern Pacific, by which Rossby wave activity would be altered (Wang et al., 2000; Feng and Li, 2011). A northwest shift of the WPSH is seen during the winter of an El Niño event, associated with southwesterly anomalies over south China during the winter of 1997, indicating a weakening in the climatological wind and leading to enhanced $\mathrm{AC}$ over south China. Therefore, the high level of AC over eastern China during winter 1997 results from the combined role of the NAO and El Niño, and the high concentrations over central China in the winter of 2002 are attributed to the NAO.
The possible reason for the asymmetric influence of the NAO on the AC was further explored. When the autumn NAO is in positive polarity, for example in two positive cases in 1986 and 1992, the associated underlying SST anomalies (figure not shown), particularly the tripole SST pattern, are not as evident as those shown in the negative NAO. This result may provide a possible explanation for the asymmetric relationship in the different phases of the NAO and $\mathrm{AC}$, and it implies the complexity of atmosphere-ocean feedback in the North Atlantic. This merits further exploration related to why the linkage between the NAO and underlying SST is nonlinear and what process is responsible for their nonlinear relationship.

As noted above, the influence of the NAO on the AC only manifests during its negative phase, and the impact of the ENSO is only significant during its warm events. However, the relationship between the previous autumn and following winter ENSO is insignificant, and thus it is of interest to establish the nonlinear relationship among them and investigate why there is strong asymmetry in the relationships. Zhang et al. $(2015,2019)$ explored the complex linkage between the boreal winter NAO and ENSO with the former lagged for 1 month, indicating that the nonlinear relationship of the NAO and ENSO is modulated by interdecadal variation in the Atlantic Multi-Decadal Oscillation. In addition, Wu et al. (2009) have illustrated the coordinated impacts of the NAO and ENSO in modulating the interannual variation of the EASM; however, it has not been shown to determine the AC yet. Therefore, it is of interest to further explore whether the NAO and ENSO affect the AC over China in other seasons, as well as the process involved. Furthermore, the present work is based on model simulations, and due to the limitations of the model simulations, only interannual variations are considered. As both the NAO and ENSO show strong interdecadal variations for a longer period, i.e., 18502017 (figure not shown), the NAO during the period 19862006 is generally located in the positive phase, whereas it is in the negative phase during the period 1955-1970; therefore, it is important to determine the interdecadal modulation of the NAO in the distribution of AC.

The role of rainfall in influencing the $\mathrm{AC}$ shows uncertainties, i.e., a positive effect over south China but not for central China. This result is similar to that of Wu (2014), showing that the impact of wet deposition on the AC has a regional and seasonal dependence. This may be due to the fact that the climatological winter rainfall over central China is much less than that over south China (figure not shown). In addition, the meteorological backgrounds of south China and central China are different: baroclinic over central China and barotropic over south China (Fig. 9 vs. 10), indicating the importance of climatology background in impacting the spatial distribution of AC. In addition, both the NAO and ENSO show significant correlations with AC over northwest China (Fig. 4); however, the interannual variation (Fig. 2) and anomalies (Fig. 5) in AC over those regions are relatively 
small. Therefore, the AC variation over those regions are not discussed.

Finally, the impact of the NAO and El Niño on the AC during boreal winter was investigated based on GEOS-Chem simulations. The coordinated role of the NAO and El Niño in affecting the distribution of AC over eastern China is highlighted by comparing this effect with the role of the NAO alone. The result indicates that the influence of meteorological factors impacting AC is complicated. Future work will investigate the combined role of tropical and extratropical signals in seasonal AC to better understand the variation across seasons and to determine the possible contribution of natural variability to the current aerosol loading over China.

Data availability. The HadISST dataset is available online at http:// www.metoffice.gov.uk/hadobs/hadisst/data/download.html (last access: 11 August 2019, Rayner et al., 2003). The NCEP/NCAR reanalyses are available at http://www.esrl.noaa.gov/psd/data/ gridded/ (last access: 11 August 2019, Kalnay et al., 1996). The model output used in the figures of this study is available at Zenodo (https://doi.org/10.5281/zenodo.3247326, last access: $11 \mathrm{Au}-$ gust 2019).

Author contributions. JF, JL, and HL designed the research. JF and JZ performed the data analysis and simulations. JF led the writing and prepared all figures. All the authors discussed the results and commented on the paper.

Competing interests. The authors declare that they have no conflict of interest.

Financial support. This research has been supported by the National Natural Science Foundation of China (grant nos. 41790474, 41705131, and 41530424).

Review statement. This paper was edited by Jianping Huang and reviewed by two anonymous referees.

\section{References}

Aw, J. and Kleeman, M. J.: Evaluating the first-order effect of intra-annual temperature variability on urban air pollution, J. Geophys. Res.-Atmos., 108, D12, 4365, https://doi.org/10.1029/2002JD002688, 2003.

Bey, I., Jacob, D. J., Yantosca, R. M., Logan, J. A., Field, B. D., Fiore, A. M., Li, Q. B., Liu, H. Y., Mickley, L. J., and Schultz, M. G.: Global modeling of tropospheric chemistry with assimilated meteorology: Model description and evaluation, J. Geophys. Res., 106, 23073-23095, https://doi.org/10.1029/2001JD000807, 2001.
Cai, W. J. and Cowan, T.: La Niña Modoki impacts Australia autumn rainfall variability, Geophys. Res. Lett., 36, L12805, https://doi.org/10.1029/2009GL037885, 2009.

Charney, J. G. and Shukla, J.: Predictability of monsoons, in: Monsoon Dynamics, edited by: Lighthill, J. and Pearce, R. P., Cambridge Univ. Press, New York, 99-109, 1981.

Chen, B. Q. and Yang Y. M.: Remote sensing of the spatio-temporal pattern of aerosol over Taiwan Strait and its adjacent sea areas, Acta Sci. Circ., 28, 2597-2604, 2008.

Duan, F. K., He, K. B., Ma, Y. L., Yang, F. M., Yu, X. C., Cadle, S. H., Chan, T., and Mulawa, P. A.: Concentration and chemical characteristics of $\mathrm{PM}_{2.5}$ in Beijing, China: 2001-2002, Sci. Total Environ., 355, 264-275, https://doi.org/10.1016/j.scitotenv.2005.03.001, 2006.

Feng, J. and Li, J. P.: Influence of El Niño Modoki on spring rainfall over south China, J. Geophys. Res.-Atmos., 116, D13102, https://doi.org/10.1029/2010JD015160, 2011.

Feng, J., Zhu, J. L., and Li, Y.: Influences of El Niño on aerosol concentrations over eastern China, Atmos. Sci. Lett., 17, 422430, https://doi.org/10.1002/asl.674, 2016a.

Feng, J., Li, J. P., Zheng, F., Xie, F., and Sun, C.: Contrasting impacts of developing phases of two types of El Niño on southern China rainfall, J. Meteorol. Soc. Jpn., 94, 359-370, https://doi.org/10.2151/jmsj.2016-019, 2016b.

Feng, J., Li, J. P., J. Zhu, J. L., Liao, H., and Yang, Y.: Simulated contrasting influences of two La Niña Modoki events on aerosol concentrations over eastern China, J. Geophys. Res.-Atmos., 122, 2734-2749, https://doi.org/10.1002/2016JD026175, 2017.

Gong, D. Y., Wang, S. W., and Zhu, J. H.: East Asian winter monsoon and Arctic Oscillation, Geophys. Res. Lett., 28, 2073-2076, https://doi.org/10.1029/2000GL012311, 2001.

Hansen, J., Sato, M., and Ruedy, R.: Radiative forcing and climate response, J. Geophys. Res., 102, 6831-6864, https://doi.org/10.1029/96JD03436, 1997.

Harrison, D. E. and Larkin, N. K.: Seasonal U.S. temperature and precipitation anomalies associated with El Niño: Historical results and comparison with 1997-98, Geophys. Res. Lett., 25, 3959-3962, https://doi.org/10.1029/1998GL900061, 1998.

Hurrell, J. W.: Decadal trends in the North Atlantic Oscillation: Regional temperature and precipitation, Science, 269, 676-679, https://doi.org/10.1126/science.269.5224.676, 1995.

IPCC: Climate change: The physical science basis, Intergovernmental Panel on Climate Change, Cambridge University Press, Cambridge, UK, 2013.

Jeong, J. I. and Park, R. J.: Winter monsoon variability and its impacts on aerosol concentrations in East Asia, Environ. Poll., 221, 285-292, https://doi.org/10.1016/j.envpol.2016.11.075, 2017.

Jerez, S., Jimenez-Guerrero, P., Montávez, J. P., and Trigo, R. M.: Impact of the North Atlantic Oscillation on European aerosol ground levels through local processes: a seasonal model-based assessment using fixed anthropogenic emissions, Atmos. Chem. Phys., 13, 11195-11207, https://doi.org/10.5194/acp-13-111952013, 2013.

Jiang, Y. Q., Yang, X. Q., Liu, X. H., Yang, D. J., Sun, X. G., Wang, M. H., Ding, A. J., Wang, T. J., and Fu, C. B.: Anthropogenic aerosol effects on East Asian winter monsoon: The role of black carbon-induced Tibetan Plateau warming, J. Geophys. Res.-Atmos., 122, 5883-5902, https://doi.org/10.1002/2016JD026237, 2017. 
Kalnay, E., Kanamitsu, M., Kistler, R., Colliins, W., Deaven, D., Gandin, L., Iredell, M., Saha, S., White, G., Woollen, J., Zhu, Y., Chelliah, M., Ebisuzaki, W., Higgins, W., Janowiak, J., Mo, K. C., Ropelewski, C., Wang, J., Leetmaa, A., Reynolds, R., Jenne, R., and Joseph, D.: The NCEP/NCAR 40-Year Reanalysis Project, B. Am. Meteorol. Soc., 77, 437-472, https://doi.org/10.1175/15200477(1996)077<0437:TNYRP>2.0.CO;2, 1996.

Karori, M. A., Li, J. P., and Jin, F. F.: The asymmetric influence of the two types of El Niño and La Niña on summer rainfall over southeast China, J. Climate, 26, 4567-4582, https://doi.org/10.1175/JCLI-D-12-00324.1, 2013.

Kleeman, M.: A preliminary assessment of the sensitivity of air quality in California to global change, Clim. Change, 87, 273292, https://doi.org/10.1007/s10584-007-9351-3, 2008

Li, J. P. and Ruan, C. Q.: The North Atlantic-Eurasian teleconnection in summer and its effects on Eurasian climates, Environ. Res. Lett., 13, 024007, https://doi.org/10.1088/17489326/aa9d33, 2018.

Li, J. P. and Wang, J. X. L.: A new North Atlantic Oscillation index and its variability, Adv. Atmos. Sci., 20, 661-676, https://doi.org/10.1007/BF02915394, 2003.

Li, Y., Ma, B. S., Feng, J., and Lu, Y.: Influence of the strongest central Pacific ENSO events on the precipitation in eastern China, Int. J. Climatol., 39, 3076-3090, https://doi.org/10.1002/joc.6004, 2019.

Liao, H., Henze, D. K., Seinfeld, J. H., Wu, S. L., and Mickley, L. J.: Biogenic secondary organic aerosol over the United States: Comparison of climatological simulations with observations, J. Geophys. Res., 112, D06201, https://doi.org/10.1029/2006JD007813, 2007.

Liao, H., Chang, W., and Yang, Y.: Climatic effects of air pollutants over China: A review, Adv. Atmos. Sci., 32, 115-139, https://doi.org/10.1007/s00376-014-0013-x, 2015.

Liu, H., Jacob, D. J., Bey, I., and Yantosca, R. M.: Constraints from ${ }^{210} \mathrm{~Pb}$ and ${ }^{7} \mathrm{Be}$ on wet deposition and transport in a global three-dimensional chemical tracer model driven by assimilated meteorological fields, J. Geophys. Res., 106, 1210912128, https://doi.org/10.1029/2000JD900839, 2001.

Lou, S. J., Russell, L. M., Yang, Y., Xu, L., Lamjiri, M. A., DeFlorio, M. J., Miller, A. J., Ghan, S. J., Liu, Y., and Singh, B.: Impacts of the East Asian monsoon on springtime dust concentrations over China, J. Geophys. Res.-Atmos., 121, 8137-8152, https://doi.org/10.1002/2016JD024758, 2016.

Lou, S. J., Yang, Y., Wang, H. L., Smith, S. J., Qian, Y., and Rasch, P. J.: Black carbon amplifies haze over the North China Plain by weakening the East Asian winter monsoon, Geophys. Res. Lett., 45, 452-460, https://doi.org/10.1029/2018GL080941, 2018.

Mao, Y.-H., Liao, H., and Chen, H.-S.: Impacts of East Asian summer and winter monsoons on interannual variations of mass concentrations and direct radiative forcing of black carbon over eastern China, Atmos. Chem. Phys., 17, 4799-4816, https://doi.org/10.5194/acp-17-4799-2017, 2017.

Marshall, J., Johnson, H., and Goodman, J.: A study of the interaction of the North Atlantic Oscillation with ocean circulation, J. Climate, 14, 1399-1421, https://doi.org/10.1175/15200442(2001)014<1399:ASOTIO>2.0.CO;2, 2001.

Moulin, C., Lambert, C. E., Dulac, F., and Dayan, U.: Control of atmospheric export of dust from North Atlantic by the North Atlantic Oscillation, Nature, 3877, 691-694, https://doi.org/10.1038/42679, 1997.

Rasmusson, E. M. and Carpenter, T. H.: Variations in tropical sea surface temperature and surface wind fields associated with the Southern Oscillation/El Niño, Mon. Weather Rev., 110, 354-384, https://doi.org/10.1175/15200493(1982)110<0354:VITSST>2.0.CO;2, 1982.

Rayner, N. A., Parker, D. E., Horton, E. B., Folland, C. K., Alexander, L. V., and Rowell, D. P.: Global analyses of sea surface temperature, sea ice, and night marine air temperature since the late nineteenth century, J. Geophys. Res., 108, 4407, https://doi.org/10.1029/2002JD002670, 2003.

Ropelewski, C. F. and Halpert, M. S.: Global and regional scale precipitation patterns associated with the El Niño/Southern Oscillation, Mon. Weather Rev., 115, 1606-1626, https://doi.org/10.1175/15200493(1987)115<1606:GARSPP>2.0.CO;2, 1987.

Singh, A. and Palazoglu, A.: Climatic variability and its influence on ozone and PM pollution in 6 non-attainment regions in the United States, Atmos. Environ., 51, 212-224, https://doi.org/10.1016/j.atmosenv.2012.01.020, 2012.

Trenberth, K. E.: The definition of El Niño, B. Am. Meteorol. Soc., 78, 2771-2777, https://doi.org/10.1175/15200477(1997)078<2771:TDOENO>2.0.CO;2, 1997.

Visbeck, M. H., Hurrell, J. W., Polvani, L., and Cullen, H. M.: The North Atlantic Oscillation: past, present, and future, P. Natl. Acad. Sci. USA, 98, 12876-12877, https://doi.org/10.1073/pnas.231391598, 2001.

Wang, B., Wu, R. G., and Fu, X. H.: Pacific-East Asian teleconnection: how does ENSO affect East Asian Climate?, J. Climate, 13, 1517-1536, https://doi.org/10.1175/15200442(2000)013<1517:PEATHD>2.0.CO;2, 2000.

Wang, Y. H., Jacob, D. J., and Logan, J. A.: Global simulation of tropospheric $\mathrm{O}_{3}-\mathrm{NO}_{x}$-hydrocarbon chemistry 1 . model formulation, J. Geophys. Res., 103, 10713-10725, https://doi.org/10.1029/98JD00158, 1998.

Watanabe, M. and Nitta, T.: Decadal changes in the atmospheric circulation and associated surface climate variations in the Northern Hemisphere winter, J. Climate, 12, 494-509, https://doi.org/10.1175/15200442(1999)012<0494:DCITAC>2.0.CO;2, 1999.

Weng, H. Y., Behera, S. K., and Yamagata, T.: Anomalous winter climate conditions in the Pacific rim during recent El Niño Modoki and El Niño events, Clim. Dynam., 32, 663-674, https://doi.org/10.1007/s00382-008-0394-6, 2009.

Wesely, M. L.: Parameterization of surface resistances to gaseous dry deposition in regional-scale numerical models, Atmos. Environ., 23, 1293-1304, https://doi.org/10.1016/00046981(89)90153-4, 1989.

$\mathrm{Wu}, \mathrm{J}$. and $\mathrm{Wu}, \mathrm{Z}$. W.: Interdecadal change of the spring NAO impact on the summer Pamir-Tienshan snow cover, Int. J. Climatol., 39, 629-642, https://doi.org/10.1002/joc.5831, 2018.

$\mathrm{Wu}$, R. G.: Seasonal dependence of factors for year-toyear variations of South China aerosol optical depth and Hong Kong air quality, Int. J. Climatol., 34, 3204-3220, https://doi.org/10.1002/joc.3905, 2014.

Wu, Z. W. and Lin, H.: Interdecadal variability of the ENSO-North Atlantic Oscillation connection in boreal summer, Q. J. Roy. Me- 
teor. Soc., 138, 1668-1675, https://doi.org/10.1007/s00382-0142361-8, 2012

$\mathrm{Wu}, \mathrm{Z}$. W. and Zhang, P.: Interdecadal variability of the megaENSO-NAO synchronization in winter, Clim. Dynam., 45, 11171128, https://doi.org/10.1007/s00382-014-2361-8, 2015.

Wu, Z. W., Wang, B., Li, J. P., and Jin, F.-F.: An empirical seasonal prediction model of the east Asian summer monsoon using ENSO and NAO, J. Geophys. Res., 114, D18120, https://doi.org/10.1029/2009JD011733, 2009.

Wu, Z. W., Li, J. P., Jiang, Z. H., He, J. H., and Zhu, X. Y.: Possible effects of the North Atlantic Oscillation on the strengthening relationship between the East Asian summer monsoon and ENSO, Int. J. Climatol., 32, 794-800, https://doi.org/10.1002/joc.2309, 2012.

Wu, Z. W., Li, J. P., Jiang, Z. H., and He, J. H.: Predictable climate dynamics of abnormal East Asian winter monsoon: oncein-a-century snowstorms in 2007/2008 winter, Clim. Dynam., 37, 1661-1669, https://doi.org/10.1007/s00382-010-0938-4, 2011.

Xie, S. P.: Satellite observations of cool ocean-atmosphere interaction, B. Am. Meteorol. Soc., 85, 195-208, https://doi.org/10.1175/BAMS-85-2-195, 2004.

$\mathrm{Xu}$, H. L., Feng, J., and Sun, C.: Impact of preceding summer North Altantic Oscillation on early autumn precipitation over central China, Atmos. Ocean. Sci. Lett., 6, 417-422, https://doi.org/10.3878/j.issn.1674-2834.13.0027, 2013.

Xuan, J., Liu, G. L., and Du, K.: Dust emission inventory in northern China, Atmos. Environ., 34, 4565-4570, https://doi.org/10.1016/S1352-2310(00)00203-X, 2000.

Yang, Y., Liao, H., and Li, J.: Impacts of the East Asian summer monsoon on interannual variations of summertime surfacelayer ozone concentrations over China, Atmos. Chem. Phys., 14, 6867-6879, https://doi.org/10.5194/acp-14-6867-2014, 2014.

Yang, Y., Liao, H., and Lou, S. J.: Increase in winter haze over eastern China in the past decades: Roles of variations in meteorological parameters and anthropogenic emissions, J. Geophys. Res.-Atmos., 121, 13050-13065, https://doi.org/10.1002/2016JD025136, 2016.

Yang, Y., Russell, L. R., Lou, S. J., Liao, H., Guo, J. P., Liu, Y., Singh, B., and Ghan, S. J.: Dust-wind interactions can intensify aerosol pollution over eastern China, Nat. Commun., 8, 15333, https://doi.org/10.1038/ncomms15333, 2017.

Ye, X. and Wu, Z. W.: Contrasting impacts of ENSO on the interannual variations of summer runoff between the upper and mid-lower reaches of the Yangtze river, Atmosphere, 9, 478, https://doi.org/10.3390/atmos9120478, 2018.
Yue, X. and Unger, N.: Aerosol optical depth thresholds as a tool to assess diffuse radiation fertilization of the land carbon uptake in China, Atmos. Chem. Phys., 17, 1329-1342, https://doi.org/10.5194/acp-17-1329-2017, 2017.

Zhang, L., Liao, H., and Li, J. P.: Impacts of Asian summer monsoon on seasonal and interannual variations of aerosols over eastern China, J. Geophys. Res., 115, D00K05, https://doi.org/10.1029/2009JD012299, 2010.

Zhang, P., Wang, B., and Wu, Z. W.: Weak El Niño and winter climate in the mid-high latitude Eurasia, J. Climate, 32, 402-421, https://doi.org/10.1175/JCLI-D-17-0583.1, 2019a.

Zhang, P., Wu, Z. W., and Li, J. P.: Reexamining the relationship of La Niña and the East Asian winter monsoon, Clim. Dynam., https://doi.org/10.1007/s00382-019-04613-7, 2019b.

Zhang, R., Sumi, A., and Kimoto, M.: Impact of El Niño on the East Asian monsoon: A Diagnostic Study of the "86/87" and "91/92" events, J. Meteorol. Soc. Jpn., 74, 49-62, https://doi.org/10.2151/jmsj1965.74.1_49, 1996.

Zhang, R. H., Sumi, A., and Kimoto, M.: A diagnostic study of the impact of El Niño on the precipitation in China, Adv. Atmos. Sci., 16, 229-241, https://doi.org/10.1007/BF02973084, 1999.

Zhang, W. J., Wang, L., Xiang, B. Q., He, J. H.: Impacts of two types of La Niña on the NAO during boreal winter, Clim. Dynam., 44, 1351-1366, https://doi.org/10.1007/s00382-014-2155-z, 2015.

Zhang, W. J., Mei, X. B., Geng, X., Turner, A. G., and Jin, F.-F.: A nonstationary ENSO-NAO relationship due to AMO modulation, J. Climate, 32, 33-43, https://doi.org/10.1175/JCLI-D-180365.1, 2019.

Zheng, F., Li, J. P., Li, Y. J., Zhao, S., and Deng, D. F.: Influence of the Summer NAO on the Spring-NAO-Based Predictability of the East Asian Summer Monsoon, J. Appl. Meteorol. Clim., 55, https://doi.org/10.1175/JAMC-D-15-0199.1, 2016.

Zhu, J. L., Liao, H., and Li, J. P.: Increases in aerosol concentrations over eastern China due to the decadal-scale weakening of the East Asian summer monsoon, Geophys. Res. Lett., 39, L09809, https://doi.org/10.1029/2012GL051428, 2012.

Zuo, J. Q., Li, W. J., Sun, C. H., Xu, L., and Ren, H. L.: Impact of the North Atlantic sea surface temperature tripole on the East Asian summer monsoon, Adv. Atmos. Sci., 30, 1173-1186, https://doi.org/10.1007/s00376-012-2125-5, 2013. 